\title{
Micromorphological Observation of the Anterior Gut of Sulawesi Medaka Fish (Oryzias celebensis)
}

\author{
Dwi Kesuma Sari ${ }^{*}$, Irma Andriani ${ }^{2}$ and Khusnul Yaqin ${ }^{3}$
}

${ }^{1}$ Study Program of Veterinary Medicine, Faculty of Medicine, Hasanuddin University, Jl. Perintis kemerdekaan Km. 10, Makassar, South Sulawesi, Indonesia

${ }^{2}$ Pstudy Program of Biology, Faculty of Mathematics and Natural Sciences, Hasanuddin University, Indonesia

${ }^{3}$ Faculty of Marine Sciences and Fisheries, Hasanuddin University, Indonesia

*Corresponding author

A B S T R A C T

\section{Keywords}

Sulawesi medaka fish, Anterior gut, Buccal cavity, Oesophagus

Article Info

Accepted:

26 January 2018

Available Online:

10 February 2018
The use of medaka fish as a candidate animal model has been started which has similarities with the Zebra fish that was developed as an animal model. Sulawesi medaka fish (Oryzias celebensis) is a type of medaka fish that are endemic in the region of South Sulawesi. This research aims to observe the histology of anterior gut of Sulawesi medaka fish. Histological study on the anterior gut of Sulawesi medaka fish using buccal cavity and oesophagus organs. Histological observation showed that the mouth and buccal cavity are shared by the respiratory and digestive systems. Also in Sulawesi medaka fish we found the lining of the buccal cavity consists of mucoid epithelium on a thick basement membrane with numerous goblet cells. In general the structure of the anterior gut system in Sulawesi medaka fish similar with Zebra fish as well as other Teleostei fish.

\section{Introduction}

Fish medaka (Oryzias sp) is a fish that has several advantages as an experimental animal that is easy to nurseries, the reproductive cycle is short (maturation initial 2 months), embryos are transparent, the generation time is short, the genome size is small and has had a construction of transgenic (Naruse et al., 1985; Denny et al., 1998; Ishikawa, 2000). Some biological information to the molecular systematics of medaka fish, especially the Japanese medaka fish (Oryzias latipes) is also widely found (Andriani and Hassan, 2013; Takehana et al., 2015). Needs medaka fish as an animal model has made researchers using medaka fish as animals test to create a wide variety of strains of medaka fish Oryzias latipes.

But in Indonesia as a distribution center of medaka fish species, information about particular medaka fish endemic to Sulawesi Island as Oryzias celebensis still very poor and have not been domesticated as well as to be further explored. Medaka fish as well as 
Zebra fish have started to be used as experimental animals. Some mutant medaka fish species have also been made for screening diabetes drugs, cancer, especially skin cancer and other degenerative diseases.

Medaka (Oryzias sp) including a group of small fish on the taxonomic belonging to the family Adrianichthyidae (Kottelat et al.,1993; Nelson, 2006). The distribution of these fish covering a wide area from India to Japan and South along the islands of the Indo Australian in the Wallacea line, namely Timor and Sulawesi (Moss and Wilson, 1998; Parenti, 2008). The discovery of the new species of medaka fish species is also increasing (Parenti and Soeroto, 2004, Parenti et al., 2013)). From exploration results the researchers showed that Sulawesi has a particularly high endemism of the fish family Adrianichthyidae.

The high endemism is not only supported by the restrictions zoogeography as the island and the line of Wallacea Weber, but also because this is not a group of fish traded so the chances for migration very limited. These facts underlying the statements by some researchers that medaka fish can unravel the mystery of the evolution of the marine fauna that exist in Sulawesi

As development of Sulawesi medaka fish (Oryzias celebensis) as an animal model and in an effort to use Sulawesi medaka fish in the field of histology and pathology, research has been done of the anterior gut system in Sulawesi medaka fish. The results of this study are expected to be the gateway for the development of medaka fish as an animal model.

This research aims to develop medaka fish as an animal model through histological observation, especially on the observation of the anterior gut of Sulawesi medaka fish.

\section{Materials and Methods}

The samples of Sulawesi medaka fish about six adult fishes with average of size and weight. Sulawesi medaka fish were obtained from Pattunuang river, Karst, Rammangrammang, Maros, South Sulawesi. The fishes and then kept in aquariums for temporary before sampling. Fish samples and then stored in $10 \%$ neutral buffered formalin. The Sulawesi medaka fish sizes are small and the observations made by one part of the body of the fish. The fishes are processed in the process of further histotechnique (Kiernan, 1990). Samples were dehydrated with graded series alcohol and clearing using xylol before embedding with paraffin. The tissues were then cut using microtome with $4 \mu \mathrm{m}$ thickness, then samples were stained using Mayer's Hematoxylin eosin (HE) and others histochemical staining such as Alcian Blue staining (AB) and Periodic Acid staining (PAS) (Kiernan, 1990). Observations were made under a microscope which has been connected to the camera microscope (Olympus 22X with advanced Optilab) and also analyzed with image $\mathrm{J}$ programme.

\section{Results and Discussions}

A comprehensive study of the histology of the anterior gut of Sulawesi medaka fish had not been established yet al.,though few studies were conducted on the anatomy and histology of zebrafish (Menke et al., 2011). Nevertheless, this research is very important to know about feeding behavior and habitat of Sulawesi medaka fish, thus providing fundamental information for further anatomical and physiological studies. Sections were observed anterior gut such as buccal cavity and oesophagus (Figure 1). The mouth and buccal cavity are shared by the respiratory and digestive systems according to previous study (Takashima and Hibiya, 1995; Roberts and Ellis 2001). 
Fig.1 Buccal cavity. Consisted of mucoid epithelium on a thick membrane with numerous Goblet cells (arrows). A: 10x10, B, C: 40x10. A, B: HE staining, C: AB staining

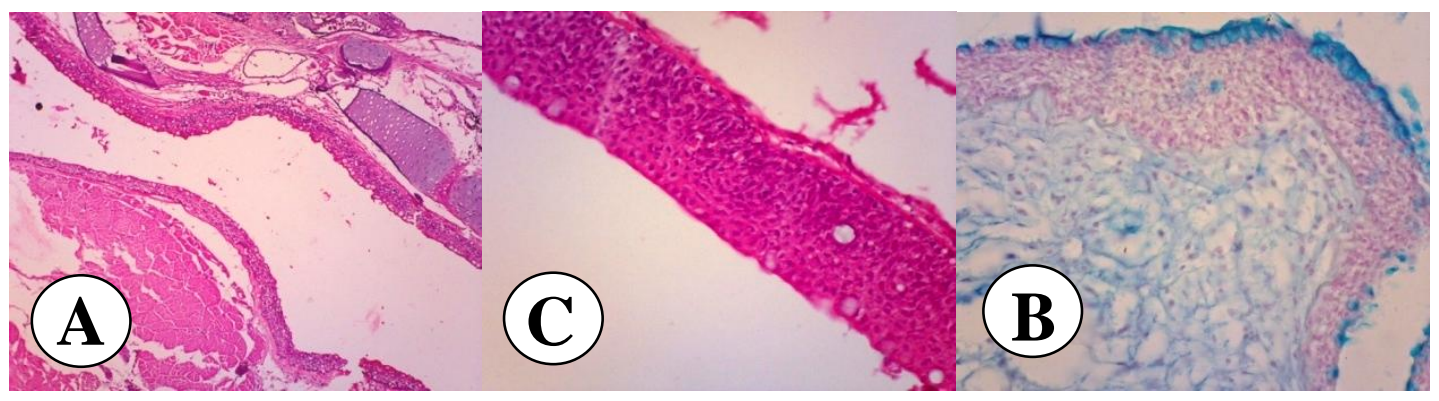

Fig.2 Buccal cavity (a) and oesophagus (b). A: 10x10, B: 40x10, HE staining

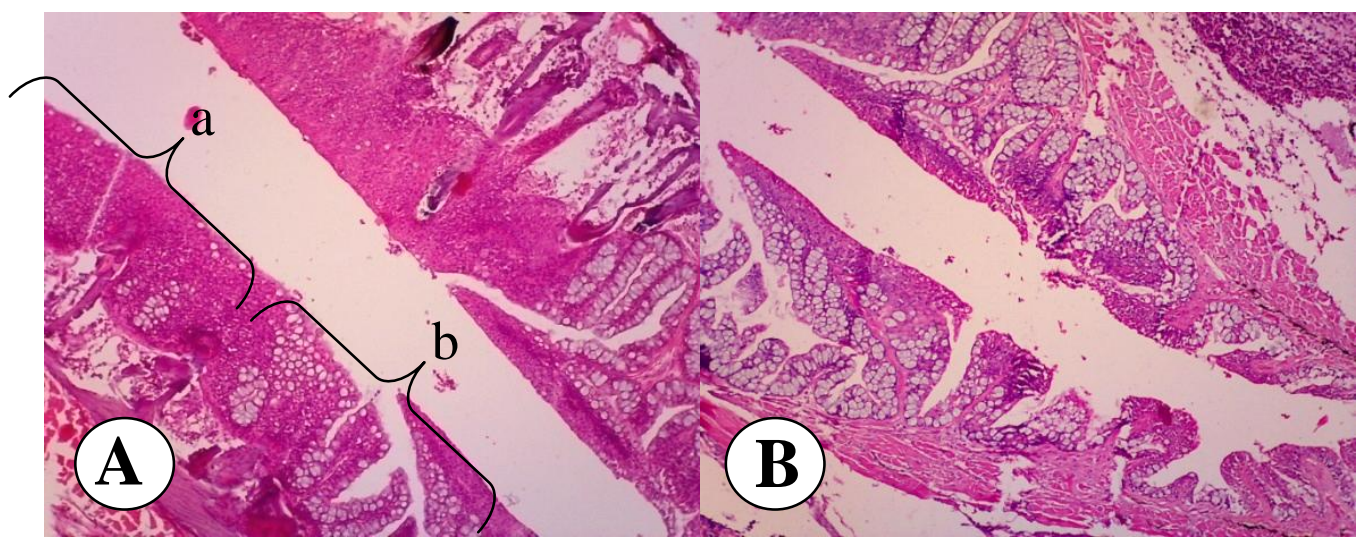

Fig.3 Oesophagus of Sulawesi medaka fish consisted of epithelial cells and Goblet cells on the mucosal. A, B: 40x10. A: HE staining, B: AB staining

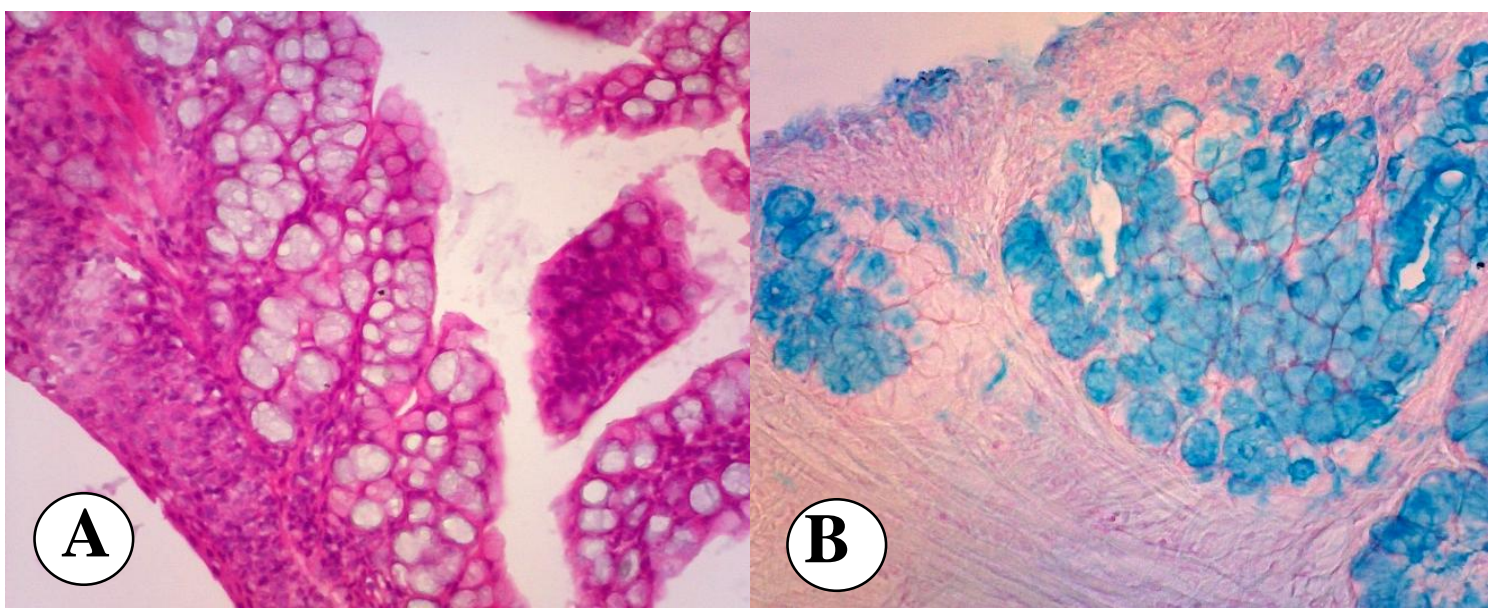

The digestive function is confined to selection, seizure, and orientation of food before transfer to the intestines. In the zebrafish, the mouth and the perioral regions have many taste buds. Also in Sulawesi medaka fish we found the lining of the buccal cavity consists of mucoid epithelium on a thick basement membrane with numerous 
goblet cells (Figure 1). In Sulawesi medaka fish as well as zebrafish the buccal cavity leads into the esophagus (Figure 2), which encompasses blind diverticula (esophageal sacs), a pharyngeal pad, and teeth where food can be ground (Roberts and Ellis, 2001) and continued to intestine.

Oesophagus of the Sulawesi medaka fish consisted of epithelial cells and Goblet cells on the mucosal areas (Figure 3). The number of Goblet cells gradually decreased from anterior to posterior region of eosophagus (Figure 2).

The Goblet cells, that abundant at anterior oesophagus and decreased in posterior region of oesophagus, produce mucoid substance and lubricates esophageal surface so that food bolus easily swallowed. The findings were similar to the oesophagus of other fishes, which demonstrated numerous mucous cells and then reacted positively to Alcian blue and PAS stains (Al Abdulhadi, 2013). Furthermore, the oesophageal mucus is important in immunological mechanisms against viral and bacterial infection and also osmoregulatory function.

The results of this observation indicate that the anterior digestive system of bungo fish and zebrafish have similarities with other teleost fish.

In general the structure of the anterior gut system in Sulawesi medaka fish similar with zebrafish as well as other Teleostei fish. The results of this study can be used as a basis in the development of studies of the digestive system in fish in particular and diseases that exist in the digestive system.

However, more studies should be carried out for deeper understanding of the digestion process and nutrient absorption of those fish as well as a fish animal model.

\section{Acknowledgments}

Researchers thanks to Annita Vury N. and Andi Resky Muwardani for helping the research and in particular to the National Grant Scheme Competence of the Ministry of Research Technology and Higher Education Batch No. 019 / SP2H / LT / DRPM / II / 2016 dan No. 005/SP2H/PPM/DPRM/IV/2017.

\section{References}

Al Abdulhadi H. A. 2013. Some comparative histological studies on alimentary tract of tilapia fish (Tilapia spilurus) and sea bream (Mylio cuvieri) Egyptian Journal of Aquatic Research. 31(1):387-397.

Andriani, I., Hassan, M. 2013. Morphological characteristic and isolation of germ cell: a preliminary study for the germ cell transplantation of celebes rainbow (Marosatherina ladigesi). Proceeding pada $2^{\text {nd }}$ International Seminar of Fish and Marine Universitas Riau, Pekan Baru.

Denny, J.S., Robert, L.S., Mead, K.E. and Yousuff, S.C. 1991. Guidelines for Culturing The Japanese Medaka Oryzias latipes. US Environmental Protection Agency. Environmental Research Laboratory-Duluth. Office of Research and Development. Duluth Minnesota 55804.

Kiernan, J.A. 1990. Histological and histochemical methods: theory and practice. Pergamon Press, Toronto.

Kinoshita, M., Murata, K., Naruse, K., Tanaka, M. 2009. Medaka. Biology, Management and Experimental Protocols. Wiley-Blackwell Publishing. Iowa USA. 419 + XXI pp.

Kottelat, M., Whitten A.J., Kartikasari, S.N and Wiriatmojo, S. 1993. Freshwater fishes of western Indoensia and Sulawesi. Periplus edition (HK) Ltd and 
EMDI Project. Republik Indonesia.

Menke, A L., Spitsbergen, J M., Wolterbeek, A.P.M., Woutersen, R.A. 2011. Normal anatomy and histology of the adult Zebrafish. Toxicologic Pathology, 39: 759-775

Moss, S.J, Wilson, M.E.J. 1998. Biogeographic implications of the Tertiary palaeogeographic evolution of Sulawesi and Borneo. Backbuys, Leiden, (pp) 133-163.

Naruse, K., Ijiri, K., Shima, A., Egami, N. 1985. The production of cloned fish in the medaka (Oryzias latipes) J.Exp.Zool. 236(3):335-41

Nelson, J.S. 2006. Fishes of the World, fourth ed. Wiley, New York

Parenti, L.R. 2008. A phylogenetic analysis and taxonomic revision of ricefishes, Oryzias and relatives (Beloniformes, Adrianichthyidae). Zool J Linn Soc 154: 494-610.

Parenti, L.R., Hadiaty, R.K., Lumbantobing, D. and Herder, P. 2013. Two New Ricefishes of the Genus Oryzias (Atherinomorpha: Beloniformes:
Adrianichthyidae) Augment the Endemic Freshwater Fish Fauna of Southeastern Sulawesi, Indonesia. Copeia 2013 (3): 403-414.2013.

Parenti, L.R., Soeroto, B. 2004. Adrianichthys roseni and Oryzias nebulosus, two new ricefishes (Atherinomorpha: Beloniformes: Adrianichthyidae) from Lake Poso, Sulawesi, Indonesia. Ichthyol Res 51: 10-19.

Pinontoan, AAS., Wahyuni. Tamsil, A., Sari, DK. 2018. Morphological study of the gills of Bungo fish (Glossogobius sp.) from Lake Tempe, South Sulawesi, Indonesia. In press.

Takashima, F and Hibiya, T. 1995. An atlas of fish histology. Normal and pathological features. Second edition. Kodansha Ltd, Tokyo, Japan.

Takehana, Y., Naruse, K., Sakaizumi, M. 2005. Molecular phylogeny of the medaka fishes genus Oryzias (Beloniformes: Adrianichthyidae) based on nuclear and mitochondrial DNA sequences. Mol Phylogenet Evol. 36(2):417-28.

\section{How to cite this article:}

Dwi Kesuma Sari, Irma Andriani and Khusnul Yaqin. 2018. Micromorphological Observation of the Anterior Gut of Sulawesi Medaka Fish (Oryzias celebensis). Int.J.Curr.Microbiol.App.Sci. 7(02): 2942-2946. doi: https://doi.org/10.20546/ijcmas.2018.702.357 